\title{
The occurrence of folic acid (pteroyl-L-monoglutamic acid) in human blood serum after small oral doses ${ }^{1}$
}

\author{
R. J. LEEMING, HeAther PORTMAN-GRAHAM, AND J. A. BLAir \\ From the General Hospital, Birmingham, and the Department of Chemistry, University of Aston \\ in Birmingham
}

SYNOPSIS Human serum folates analysed by bioautography after oral doses of $0.5 \mathrm{mg}$ folic acid (pteroyl-L-monoglutamic acid) show folic acid to be present.

Folic acid is probably only a minor dietary component but it has important therapeutic effects. Its mode of absorption and subsequent metabolism have caused much discussion. According to Baker, Frank, Feingold, Ziffer, Gellene, Leevey, and Sobotka (1965) folic acid is converted to tetrahydrofolates on transport across the human intestine but, as large amounts of 5-methyltetrahydrofolic acid were found only after two hours, the possible effects of passage through the intestine and liver could not be accurately defined. Similar results have been reported by Perry and Chanarin (1970).

If hamster everted sacs are incubated with folic acid 5-methyltetrahydrofolic acid and citrovorum factor can be demonstrated by microbiological assay (Cohen, 1965). However, these could have been derived from bacteria or from the folates in the intestinal mucosa, for although the hamster intestinal content of folates is unknown, rat intestinal mucosa contains $2.1 \mu \mathrm{g} / \mathrm{g}$ folates of which $0.46 \mu \mathrm{g}$ is $5-$ methyltetrahydrofolic acid and $0 \cdot 13 \mu \mathrm{g}$ is citrovorum factor (Sotobayashi, Rosen, and Nichol, 1966).

In two human subjects Whitehead and Cooper (1967) observed that folic acid as determined by microbiological assay appeared in serum obtained from the portal vein after oral folic acid. Butterworth, Baugh, and Krumdieck (1969), comparing the specific microbiological and radiochemical activities of ${ }^{14} \mathrm{C}$ folic acid, concluded that folic acid was not metabolized on transport. With rat everted sacs, Matty and Blair (1968), Smith, Matty, and Blair (1970a and 1970b) found only folic acid in the serosal solution when folic acid was incubated in the mucosal solution.

Bioautographic techniques (Leeming, PortmanGraham, Swan, and Blair, 1970) enable more specific chemical confirmation of the presence of folic acid

${ }^{1}$ Requests for reprints should be addressed to $R$. J. Leeming, The General Hospital, Birmingham, B4 6NH.

Received for publication 20 January 1972. and 5-methyltetrahydrofolic acid to be made and avoid the assumptions and ambiguities of identification by microbiological assay.

\section{Materials and Methods}

There were 42 normal subjects, 18 males and 24 females, with ages ranging from 17 to 52 years. Seven of the females were taking oral contraceptives.

\section{COLLECTION OF SPECIMENS}

A venous sample of blood was taken from each volunteer and $0.5 \mathrm{mg}$ folic acid given orally. Samples of blood were taken at 15 minutes, 30 minutes, 45 minutes, 60 minutes, and 120 minutes, and the serum was separated.

\section{SERUM EXTRACTION}

Of freshly separated serum, $10 \mathrm{ml}$ was added to an equal volume of $1 \%$ aqueous ascorbic acid. The mixture was heated in a boiling water bath to $80^{\circ} \mathrm{C}$, cooled in a refrigerator, and passed through $8 / 32$ in. Visking tubing under negative pressure in the dark. The clear filtrate was frozen and freeze-dried. For use the dry material was dissolved in $0.2 \mathrm{ml}$ of $1 \%$ aqueous ascorbic acid.

\section{BIOAUTOGRAPHS}

Bioautography was carried out as previously described (Leeming et al, 1970). The chromatograms were developed in $3 \%$ aqueous ammonium chloride but the extracts of the six sera from one subject were also developed in $0.5 \%$ aqueous sodium carbonate and phosphate buffer $0.1 \overline{\mathrm{M}}, p \mathrm{H} 7.0$ (Leeming et al, 1970). The RF values of the two moieties in the sera. corresponded to those of the folic acid and 5-methyltetrahydrofolic acid standards in the three solvent systems.

RECOVERY AFTER EXTRACTION

A sample of pooled serum from subjects not given 
folic acid was divided into four and an equal volume of one of the three folate analogues-citrovorum factor, 5-methyltetrahydrofolic acid, and folic acid(10 $\mathrm{ng} / \mathrm{ml}$ in $1 \%$ aqueous ascorbic acid) was added to each of three and to the fourth an equal volume of $1 \%$ aqueous ascorbic acid alone. These bioautographs were compared with others in which folates were added to serum after concentration. The fourth sample only showed a small spot corresponding to 5-methyltetrahydrofolic acid. The added folates survived the concentration process as shown by their having the same RF values as those added after concentration. In the samples where 5-methyltetrahydrofolic acid had been added only the added 5-methyltetrahydrofolic acid could be detected and folic acid was absent. Therefore the folic acid determined in later bioautographs could not have arisen by decomposition reactions.

DIFFERENTIAL MICROBIOLOGICAL ASSAYS Serum folate assays were carried out using Streptococcus faecalis (NCIB 6459) and Lactobacillus casei (NCIB 8010).

\section{Results}

The results of the bioautograms are shown in Fig. 1 and the results of the microbiological assays given in $\stackrel{\frac{0}{*}}{\text { Tables I and III. }}$
Table

The microbiological assays showed a rise in both $\vec{F}$ Streptococcus faecalis and Lactobacillus casei active folates 15 minutes after ingestion. The Streptococcus? faecalis active folate increased approximately $\frac{\overline{5}}{5}$. linearly with time to a maximum level at 60 minutes $\frac{\widehat{\sigma}}{\sigma}$ and thereafter declined. As this rise and fall of 0 Streptococcus faecalis assay paralleled the appear-ळ ance of folic acid on the bioautographs, this activity $\vec{\circ}$ was ascribed solely to the folic acid present. Strepto-coccus faecalis is inactive and Lactobacillus casei $\vec{\omega}$ active for 5-methyltetrahydrofolic acid and their? difference measures this compound (Table III). Theo serum 5-methyltetrahydrofolic acid level showed little increase in the first 15 minutes compared witho folic acid levels but increased rapidly thereafter.

\section{Discussion}

The folic acid dose was chosen as the smallest giving $\subseteq$ clearly defined results. These experiments showed $\Phi$ that when small oral doses of folic acid were given $\vec{\varphi}$ folic acid appeared in the serum and that this was $N$ slowly converted to 5-methyltetrahydrofolic acid (Blair, 1970). When the serum levels of folic acid and 5-methyltetrahydrofolic acid were plotted against

Tetrahydrofolate

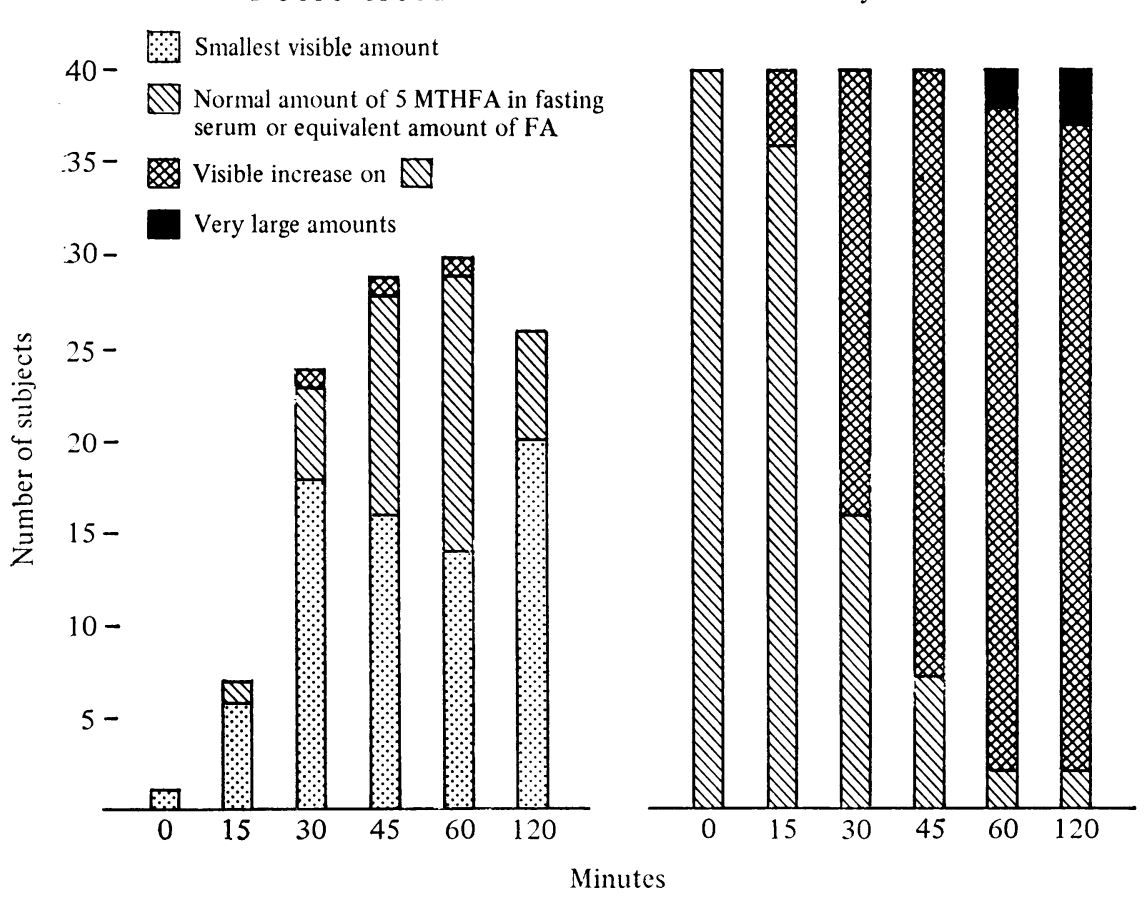

Fig. 1 Bioautograph results showing the number of subjects demonstrating the two moieties at each time interval. 


\begin{tabular}{|c|c|c|c|c|c|c|}
\hline \multirow[t]{2}{*}{ Subject } & \multicolumn{6}{|c|}{ Time in Minutes } \\
\hline & 0 & 15 & 30 & 45 & 60 & 120 \\
\hline $\begin{aligned} & 42 \text { Total } \\
& 18 \text { Males } \\
& 24 \text { Females } \\
& 7 \text { Females on oral contraceptives } \\
& 17 \text { Females not on oral contraceptives }\end{aligned}$ & $\begin{array}{l}5.6 \pm 0.32 \\
5.6 \pm 0.53 \\
5 \cdot 5 \pm 0.41 \\
6.5 \pm 0.99 \\
5 \cdot 1 \pm 0.39\end{array}$ & $\begin{array}{l}6.3 \pm 0.39 \\
6.4 \pm 0.65 \\
6.2 \pm 0.49 \\
7.4 \pm 0.93 \\
5.8 \pm 0.55\end{array}$ & $\begin{array}{l}8 \cdot 2 \pm 0.49 \\
8 \cdot 3 \pm 0.95 \\
8 \cdot 1 \pm 0.51 \\
9 \cdot 3 \pm 1 \cdot 27 \\
7.7 \pm 0.48\end{array}$ & $\begin{array}{r}10.1 \pm 0.66 \\
10.4 \pm 1.32 \\
9.8 \pm 0.64 \\
10.5 \pm 1.61 \\
9.5 \pm 0.65\end{array}$ & $\begin{array}{l}11.5 \pm 0.76 \\
10.4 \pm 1.09 \\
12.3 \pm 1.03 \\
10.4 \pm 1.91 \\
13.1 \pm 1.21\end{array}$ & $\begin{array}{l}13 \cdot 2 \pm 0.89 \\
12 \cdot 1 \pm 1 \cdot 20 \\
14 \cdot 1 \pm 1 \cdot 27 \\
11 \cdot 1 \pm 1 \cdot 36 \\
15 \cdot 3 \pm 1 \cdot 63\end{array}$ \\
\hline
\end{tabular}

Table I Mean levels of folate acid in $\mathrm{L}$. casei assay ${ }^{1}$

${ }^{1}$ Results are given in $\mathrm{ng} / \mathrm{ml}$ with the standard errors of means.

\begin{tabular}{|c|c|c|c|c|c|c|}
\hline \multirow[t]{2}{*}{ Subject } & \multicolumn{6}{|c|}{ Time in Minutes } \\
\hline & 0 & 15 & 30 & 45 & 60 & 120 \\
\hline $\begin{array}{l}27 \text { Total } \\
10 \text { Males } \\
17 \text { Females } \\
5 \text { Females on oral contraceptives } \\
12 \text { Females not on oral contraceptives }\end{array}$ & $\begin{array}{l}1.5 \pm 0.13 \\
1.5 \pm 0.25 \\
1.5 \pm 0.15 \\
1.4 \pm 0.19 \\
1.6 \pm 0.21\end{array}$ & $\begin{array}{l}2 \cdot 0 \pm 0.21 \\
2 \cdot 0 \pm 0.39 \\
2 \cdot 0 \pm 0.24 \\
1.6 \pm 0.19 \\
\mathbf{2 \cdot 1} \pm \mathbf{0 . 3 3}\end{array}$ & $\begin{array}{l}2.4 \pm 0.22 \\
2.6 \pm 0.54 \\
2 \cdot 1 \pm 0.15 \\
1.8 \pm 0.19 \\
2.4 \pm 0.18\end{array}$ & $\begin{array}{l}3.0 \pm 0.24 \\
3 \cdot 2 \pm 0.47 \\
2 \cdot 8 \pm 0.27 \\
2 \cdot 2 \pm 0.25 \\
3 \cdot 1 \pm 0.35\end{array}$ & $\begin{array}{l}3.3 \pm 0.31 \\
3.5 \pm 0.58 \\
3.2 \pm 0.37 \\
2.3 \pm 0.54 \\
3.6 \pm 0.44\end{array}$ & $\begin{array}{l}2 \cdot 7 \pm 0.16 \\
2 \cdot 6 \pm 0.21 \\
2 \cdot 7 \pm 0.22 \\
2 \cdot 3 \pm 0.27 \\
2.9 \pm 0.29\end{array}$ \\
\hline
\end{tabular}

Table II Mean levels of folic acid in Str. faecalis assay

\begin{tabular}{|c|c|c|c|c|c|}
\hline \multicolumn{6}{|c|}{ Time in Minutes } \\
\hline 0 & 15 & 30 & 45 & 60 & 120 \\
\hline $4 \cdot 1$ & $4 \cdot 3$ & 5.8 & $7 \cdot 1$ & $8 \cdot 3$ & $10 \cdot 5$ \\
\hline
\end{tabular}

Table III L. casei assay minus Str. faecalis assay (5-methyltetrahydrofolic acid)

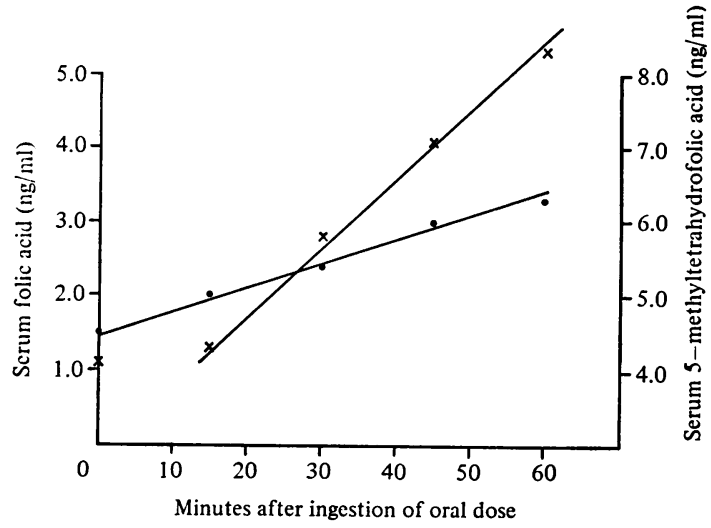

Fig. 2 Mean serum folic acid and 5-methyltetrahydrofolic acid levels plotted against time.

S. faecalis-folic acid; $X=L$. casei less $S$. faecalis5-methyltetrahydrofolic acid.

time the level of folic acid in the serum rose in the first 10 minutes while the level of 5-methyltetra- hydrofolic acid did not (Tables II and III, Fig. 2). Therefore in these experiments folic acid was transported across the intestine without being metabolized to 5-methyltetrahydrofolic acid and the conversion of folic acid to 5-methyltetrahydrofolic acid took place elsewhere than in the intestine.

We are grateful to Mr J. R. G. Beavon for assistance with the statistical analysis of the data.

\section{References}

Baker, H., Frank, O., Feingold, S., Ziffer, H., Gellene, R. A., Leevey, C. M., and Sobotka, H. (1965). The fate of orally and parenterally administered folates. Amer. J. clin. Nutr., 17, 88-95.

Blair, J. A. (1970). Toxicity of folic acid. Lancet, 1, 360.

Butterworth, C. E., Baugh, C. M., and Krumdieck, C. (1969). A study of folate absorption and metabolism in man utilizing carbon14-labeled polyglutamates synthesized by the solid phase method. J. clin. Invest., 48, 1131-1142.

Cohen, N. (1965). Differential microbiological assay in the study of folic acid absorption in vitro by everted intestinal sacs. Clin. Res., 13, 252.

Leeming, R. J., Portman-Graham, H., Swan, C. H. J., and Blair, J. A. (1970). The application of tetrazolium bioautography to the identification of folic acid derivatives. J. clin. Path., 23, 411-413.

Matty, A. J., and Blair, J. A. (1968). Folic-acid absorption in man. Lancet, 2, 977-978.

Perry, J., and Chanarin, I. (1970). Intestinal absorption of reduced folate compounds in man. Brit. J. Haemat., 18, 329-339.

Smith, M. E., Matty, A. J., and Blair, J. A. (1970a). The transport of folic acid (pteroyl-L-monoglutamic acid) across the small intestine of the rat. Gut, 11,368 .

Smith, M. E., Matty, A. J., and Blair, J. A. (1970b). The transport of pteroylglutamic acid across the small intestine of the rat. Biochim. biophys. Acta (Amst.), 219, 37-46.

Sotobayashi, H., Rosen, F., and Nichol, C. A. (1966). Tetrahydrofolate cofactors in tissues sensitive and refractory to amethopterin. Biochemistry (Wash.), 5, 3878-3882.

Whitehead, V. M., and Cooper, B. A. (1967). Absorption of unaltered folic acid from the gastrointestinal tract in man. Brit. $J$. Haemat., 13, 679-686. 